\title{
Corrigendum: A Comprehensive Infrastructure for Big Data in Cancer Research: Accelerating Cancer Research and Precision Medicine
}

\author{
Izumi V. Hinkson 1,2, Tanja M. Davidsen ${ }^{1}$, Juli D. Klemm ${ }^{1}$, Ishwar Chandramouliswaran ${ }^{3}$, \\ Anthony R. Kerlavage ${ }^{1 *}$ and Warren A. Kibbe ${ }^{1,4}$ \\ ${ }^{1}$ Center for Biomedical Informatics and Information Technology, National Cancer Institute, Rockville, MD, United States, \\ ${ }^{2}$ Science and Technology Policy Fellowship Program, American Association for the Advancement of Science, Washington, \\ DC, United States, ${ }^{3}$ Office of Genomics and Advanced Technologies, National Institute of Allergy and Infectious Diseases, \\ Bethesda, MD, United States, ${ }^{4}$ Department of Biostatistics and Bioinformatics, Duke University School of Medicine, Durham \\ NC, United States
}

Keywords: genomics, proteomics, imaging, big data, cancer, precision medicine, cloud infrastructure

OPEN ACCESS

Edited and reviewed by: Frontiers in Cell and Developmental

Biology Editorial Office,

Frontiers Media SA, Switzerland

*Correspondence: Anthony R. Kerlavage anthony.kerlavage@nih.gov

Specialty section: This article was submitted to Molecular and Cellular Oncology,

a section of the journal Frontiers in Cell and Developmental

Biology

Received: 11 October 2017 Accepted: 24 November 2017 Published: 07 December 2017

Citation:

Hinkson IV, Davidsen TM, Klemm JD, Chandramouliswaran I, Kerlavage $A R$ and Kibbe WA (2017) Corrigendum: A Comprehensive Infrastructure for Big Data in Cancer Research: Accelerating Cancer Research and Precision Medicine. Front. Cell Dev. Biol. 5:108. doi: 10.3389/fcell.2017.00108

\section{A corrigendum on}

A Comprehensive Infrastructure for Big Data in Cancer Research: Accelerating Cancer Research and Precision Medicine by Hinkson, I. V., Davidsen, T. M., Klemm, J. D., Kerlavage, A. R., and Kibbe, W. A. (2017). Front. Cell Dev. Biol. 5:83. doi: 10.3389/fcell.2017.00083

Ishwar Chandramouliswaran (currently National Institute of Allergy and Infectious Diseases) was not included as an author in the published article. The authors apologize for this error and state that this does not change the content of the article.

The original article has been updated.

\section{AUTHOR CONTRIBUTIONS}

$\mathrm{IH}$ : Manuscript writing, figure design. TD, JK, AK, and WK: Manuscript and figure revision, approval of final manuscript. IH, TD, JK, IC, AK, and WK: Management and project support for Cancer Genomics Cloud Pilots.

Conflict of Interest Statement: The authors declare that the research was conducted in the absence of any commercial or financial relationships that could be construed as a potential conflict of interest.

Copyright (c) 2017 Hinkson, Davidsen, Klemm, Chandramouliswaran, Kerlavage and Kibbe. This is an open-access article distributed under the terms of the Creative Commons Attribution License (CC BY). The use, distribution or reproduction in other forums is permitted, provided the original author(s) or licensor are credited and that the original publication in this journal is cited, in accordance with accepted academic practice. No use, distribution or reproduction is permitted which does not comply with these terms. 